JULIUSZ IWANICKI

ORCID 0000-0002-9391-1545

Uniwersytet im. Adama Mickiewicza

$w$ Poznaniu

\title{
NIEOBECNOŚĆ RELIGIOZNAWSTWA W POLSKIEJ EDUKACJI SZKOLNEJ
}

\begin{abstract}
AвSTRACT. Iwanicki Juliusz, Nieobecność religioznawstwa w polskiej edukacji szkolnej [Absence of Religious Studies in Polish School Education]. Studia Edukacyjne nr 53, 2019, Poznań 2019, pp. 407-421. Adam Mickiewicz University Press. ISSN 1233-6688. DOI: 10.14746/se.2019.53.23

The article analyzes the problem of the absence of religious studies in Polish school education. The first part explains the status of religious studies as a discipline. In the main part, the school core curriculum in the primary school was analyzed with respect to the humanities. Then, reference was made to the presence of religion in school as catechesis. The final part presents earlier attempts to introduce religious studies to schools as well as their own ideas on this issue.
\end{abstract}

Key words: religious studies, Polish education, humanistic education

\section{Wstęp}

Można przyjąć, że edukacja humanistyczna w szerokim znaczeniu to kształcenie w obszarze przedmiotów dotyczących ogólnie rozumianego człowieczeństwa, kultury i języka. Humanizm historyczny inspirowany włoskim Odrodzeniem oznaczał studenta bądź profesora zainteresowanego konkretnymi naukami, co w tamtej epoce oznaczało przede wszystkim studia filologiczne, związane ze zgłębianiem kultury greckiej i łacińskiej ${ }^{1}$. Wbrew potocznym wyobrażeniom edukacja humanistyczna w Renesansie nie ograniczała się do zgłębiania źródeł antycznych i wiedzy językoznawczej - humanista w dobrym znaczeniu tego słowa oznaczał również kogoś, kto interesuje się światem przyrody, o czym świadczyła aktywność włoskich ośrodków umy-

\footnotetext{
${ }^{1}$ Z. Drozdowicz, Filozofia włoska w epoce Odrodzenia i Oświecenia, Poznań 2012, s. 19-20.
} 
słowych w Bolonii, Florencji i Padwie oraz lista ich znakomitych absolwentów, uczonych znanych w całej Europie, w tym polskich znamienitych wychowanków tego okresu².

W obecnym zakresie edukacji humanistycznej na szczeblu podstawowym i średnim możemy wskazać konkretne przedmioty nauczania, które realizują wytyczne kształcenia w zakresie kultury i języka. W przeanalizowanej przeze mnie Podstawie programowej kształcenia ogólnego dla szkoły podstawowej ${ }^{3}$ wskazałbym najważniejsze przedmioty humanistyczne, obecne we współczesnej edukacji: język polski, język obcy nowożytny, historia, wiedza o społeczeństwie i etyka.

Podczas analizy dokumentu zwróciłem uwagę na obszar nieobecny w zapisach lub bardzo rozproszony wśród różnych treści nauczania wyżej wymienionych przedmiotów szkolnych. Ten obszar terra incognita to religioznawstwo. Być może jedną z przyczyn stanowi to, iż nawet na poziomie akademickim nie jest to nadal zbyt widoczna dyscyplina, choć przecież uwzględniona w najnowszym wykazie Ministerstwa Nauki i Szkolnictwa Wyższego w dyscyplinie nauki o kulturze i religii ${ }^{4}$. Zanim przejdę do analizy podstawy programowej kształcenia ogólnego szkoły podstawowej, należałoby zatem krótko wyjaśnić, jak obecnie możemy rozumieć religioznawstwo?

\section{Status religioznawstwa}

Religioznawstwo jest dziedziną, która rozwinęła się jako świecka nauka w XIX wieku. Z jednej strony religioznawstwo było inspirowane filozofią Hegla, na kanwie której powstawały także prace akademickie obejmujące problemy religioznawcze ${ }^{5}$. W drugiej połowie XIX wieku nauki o religii były silnie metodologicznie powiązane $\mathrm{z}$ historią, etnologią, archeologią, a także naukami językoznawczymi. Pierwsze katedry religioznawstwa (wtedy jeszcze

2 S. Kot, Historia wychowania, t. 1, Warszawa 1994, s. 242-250.

3 Rozporządzenie Ministra Edukacji Narodowej z 14 lutego 2017 r. w sprawie podstawy programowej wychowania przedszkolnego oraz podstawy programowej kształcenia ogólnego dla szkoły podstawowej, w tym dla uczniów z niepełnosprawnością intelektualną w stopniu umiarkowanym lub znacznym, kształcenia ogólnego dla branżowej szkoły I stopnia, kształcenia ogólnego dla szkoły specjalnej przysposabiającej do pracy oraz kształcenia ogólnego dla szkoły policealnej, https://www.infor.pl/akt-prawny/DZU.2017.039.0000356,rozporzadzenie-ministra-edukacji-narodowej-w-sprawie-podstawy-programowej-wychowania-przedszkolnego-oraz-podstawy-programowej-ksztalcenia-ogolnego-dla-szkoly-podstawowej-w-tym-dla-ucznioW-z-niepelnosp.html [dostęp: 15.02.2019].

4 Zależności między nową klasyfikacją dziedzin i dyscyplin a wcześniej obowiązującym wykazym i systematyka OECD, https://konstytucjadlanauki.gov.pl/content/uploads/2018/09/ nowy-podzia-dyscyplin-tabela.pdf [dostęp: 24.04.2019].

5 Z. Drozdowicz (red.), Zarys encyklopedyczny religii, Poznań 1992, s. 287. 
nazywane najczęściej katedrami historii religii) zostały powołane $\mathrm{w}$ Lejdzie (1876), Amsterdamie (1878), Brukseli (1884), Rzymie (1886) i Paryżu (1887). Powstanie tych placówek naukowych było związane również z klimatem ideowym, jaki wówczas łączył się z rozwojem pozytywistycznego ewolucjonizmu, a także nowych prądów w obrębie chrześcijaństwa - protestanckiej teologii liberalnej oraz modernizmu katolickiego ${ }^{6}$. Inspiracje do rozwoju religioznawstwa płynęły zatem zarówno z poszczególnych nauk humanistycznych, jak i różnych konfesji chrześcijańskich.

W Polsce przed II wojną światową działali różni naukowcy o orientacji religioznawczej ${ }^{7}$, jednak pierwsze jednostki naukowe powstały dopiero w okresie PRL. Zakład Religioznawstwa utworzono w 1958 roku przy Instytucie Filozofii i Socjologii PAN, natomiast większy Instytut Religioznawstwa utworzono w 1974 na Uniwersytecie Jagiellońskim (obydwie placówki istnieją do dnia dzisiejszego, z tym że jednostka przy PAN obecnie nazywa się Zakład Badań nad Religią). Na Uniwersytecie im. Adama Mickiewicza od 2011 roku, na Wydziale Nauk Społecznych działa Katedra Religioznawstwa i Badań Porównawczych UAM (przekształcona z dawnego Zakładu Historii i Filozofii Religii w Instytucie Filozofii UAM), której pracownikiem jest Autor niniejszego artykułu.

Religioznawstwo jako nauka i gałąź wiedzy humanistycznej posiada kilka specyficznych cech metodologicznych. Przede wszystkim, przedmiotem zainteresowania tej dyscypliny są różne wymiary i formy religii na świecie. Religioznawców interesują zarówno religie, które już wymarły, jak również wciąż żywe pod względem instytucjonalnym i rytualnym. W tym sensie jest to nauka porównawcza, w ramach której prowadzi się studia o charakterze komparatystycznym i kulturowym (w nowej klasyfikacji Ministerstwa Nauki i Szkolnictwa Wyższego dotyczącej dyscyplin naukowych, religioznawstwo obok etnologii i kulturoznawstwa połączono $w$ jeden blok - nauki o kulturze i religii $\left.{ }^{8}\right)$. Stanowi to również o trudności tej nauki, gdyż po pierwsze - religioznawca musi mieć wysokie kwalifikacje językowe i historyczne do przedmiotu swoich badań, po drugie - z konieczności musi zawężać swoje studia do kilku wybranych religii, a nawet jednej konkretnej postaci religii, w celu zawężenia przedmiotu badań. Należy tu również pamiętać, że religia to nie tylko kościoły i świątynie - dziś często w dyskursie

${ }^{6}$ Z. Drozdowicz, Z. Stachowski (red.), Ilustrowana Encyklopedia Religii Świata. Kościoły, wyznania, kulty, sekty, nowe ruchy religijne, Poznań 2002, s. 534-535.

7 Zob. H. Hoffman, Dzieje polskich badań religioznawczych 1873-1939, Kraków 2004.

${ }^{8}$ Rozporządzenie Ministra Nauki i Szkolnictwa Wyższego z 20 września 2018 r. w sprawie dziedzin nauki i dyscyplin naukowych oraz dyscyplin artystycznych, https:/ / www.infor.pl/ akt-prawny/ DZU.2018.186.0001818,rozporzadzenie-ministra-nauki-i-szkolnictwa-wyzszego-w-sprawie-dziedzin-nauki-i-dyscyplin-naukowych-oraz-dyscyplin-artystycznych.html [dostęp: 15.02.2019]. 
religioznawczym mówi się o duchowości jako nowej i alternatywnej formie religijności ${ }^{9}$. Nie brakuje również nowych ruchów religijnych o bardzo różnorodnych inspiracjach. Często badanym zjawiskiem jest wpływ nowych mediów na religie ${ }^{10}$.

Istnieją klasyczne prace, godne polecenia, w których wybitni badacze podejmowali studia nad prawie wszystkimi religiami. Wymienić tu można osiągnięcia naukowe Mircea Eliadego, do dziś jednego z najważniejszych religioznawców ${ }^{11}$, a także wybitnego socjologa religii i filozofa społecznego Maxa Webera ${ }^{12}$. Co stanowi ważną cechę metodologiczną religioznawstwa, to jej programowa neutralność aksjologiczna oraz abstrahowanie od ontologicznego statusu sacrum. Badacze na ogół nie wypowiadają się na ten temat - i to odróżnia tę naukę od teologii (po części również od filozofii). Nie oznacza to jednocześnie, że religioznawstwo jest przeciwko teologii, czy konkretnym kościołom, przeciwnie - obecnie w Polsce zdarza się, że naukę tę z powodzeniem uprawiają również duchowni, którzy jednak na ogół przestrzegają wtedy zasady neutralności aksjologicznej w tej dziedzinie ${ }^{13}$.

Religioznawstwo jest obecne w strukturach akademickich współczesnych uczelni polskich, prowadzi się takie badania, odbywają się konferencje i kongresy z tej dyscypliny, można również $w$ kilku ośrodkach studiować tę dyscyplinę. Jak wyglądają jednak wpływy tej dyscypliny na poziomie edukacji szkolnej w Polsce?

\section{Ogólne cele kształcenia w podstawie programowej a edukacja religioznawcza}

Przeprowadzona przeze mnie analiza wskazuje, że rozwiązania obecnego kształcenia ogólnego dla szkoły podstawowej nie przewidują osobnego przedmiotu szkolnego o nazwie religioznawstwo. Jest to o tyle zastanawiająca luka, gdyż Podstawa programowa ${ }^{14}$ z 2017 ma na celu, jak czytamy na początku tego dokumentu: „wyposażenie uczniów w taki zasób wiadomości

9 A. Zduniak, Religijność, duchowość, nowa duchowość - próba teoretycznego rozgraniczenia kluczowych pojęć wspótczesnej socjologii religii, Przegląd Religioznawczy, 2017, 2(264), s. 153-166.

${ }^{10} \mathrm{~J}$. Iwanicki, Mediatyzacja treści religijnych we wspótczesnej kulturze popularnej i internetowej, Humaniora. Czasopismo Internetowe, 2017, 2(18), s. 15-26.

${ }_{11}$ Zob. M. Eliade, Traktat o historii religii, przekł. J. Wierusz-Kowalski, Warszawa 2009.

${ }_{12}$ Zob. M. Weber, Etyka gospodarcza religii światowych, przekł. T. Zatorski, G. Sowiński, D. Motak, Kraków 2006.

${ }_{13}$ Zob. J. Mariański, Sekularyzacja, desekularyzacja, nowa duchowość: studium socjologiczne, Kraków 2013.

${ }^{14}$ Rozporządzenie Ministra Edukacji Narodowej z 14 lutego 2017 r. w sprawie podstawy programowej wychowania przedszkolnego oraz podstawy programowej kształcenia ogólnego dla szkoły podstawowej. 
oraz kształtowanie takich umiejętności, które pozwalają w sposób bardziej dojrzały i uporządkowany zrozumieć świat” (pkt 9) oraz „kształtowanie postawy otwartej wobec świata i innych ludzi, aktywności w życiu społecznym oraz odpowiedzialności za zbiorowość" (pkt 11).

Jeszcze dalej można przeczytać o celach kształcenia $\mathrm{w}$ zakresie poznawczym, gdzie zwracają uwagę następujące postulaty oczekiwane od ucznia: „umiejętność rozumienia legend, faktów historycznych, tradycji, elementów kultury materialnej i duchowej oraz pojęć i symboli z nimi związanych, takich jak: rodzina, dom, naród, ojczyzna, kraj” (pkt 10) oraz „umiejętność samodzielnej eksploracji świata, rozwiązywania problemów i stosowania nabytych umiejętności w nowych sytuacjach życiowych" (pkt 12). Uważam, że brak odrębnego przedmiotu, uczącego o różnorodności religijnej współczesnego świata, w poważny sposób zakłóca realizację powyższych celów i oczekiwanych umiejętności, gdyż trudno zrozumieć świat w sposób dojrzały, a także być na niego otwartym, nie posiadając informacji na temat bogactwa religii i duchowości we współczesnej rzeczywistości społeczno-kulturowej. Jest to o tyle zastanawiające, że ustawodawca chciałby jednocześnie, aby w zakresie edukacji społecznej uczeń posiadał następującą umiejętność: „,szanuje zwyczaje i tradycje różnych grup społecznych i narodów, przedstawia i porównuje zwyczaje ludzi, np. dotyczące świąt w różnych regionach Polski, a także w różnych krajach" (pkt 9). Zasadne jest pytanie, jak szanować cudze zwyczaje ( $w$ tym te o charakterze religijnym), nie mając szerszej możliwości zapoznania się $\mathrm{z}$ nimi $\mathrm{w}$ toku edukacji humanistycznej?

Ta sama wątpliwość powstaje, kiedy czytelnik Podstawy programowej dochodzi do części XIII - Etyka, gdzie oczekuje się, że uczeń: „ma świadomość, że każdej osobie ludzkiej, także jemu, należy się szacunek, że szacunkiem należy obdarzać także wspólnoty osób - rodzinę, klasę, naród (ojczyznę), w tym wspólnotę religijną - a także symbole tych wspólnot". Aby poznać symbole innych wspólnot religijnych, oraz ich historię i znaczenie, potrzebny byłby przedmiot religioznawstwo, który jednak nie figuruje na listach lekcji szkolnych.

Studiując dalej Podstawę programową, można zwrócić uwagę na inne umiejętności, jakie miałyby być rozwijane wśród uczniów według ustawodawcy. Zwraca tu uwagę trzeci punkt: „poszukiwanie, porządkowanie, krytyczna analiza oraz wykorzystanie informacji z różnych źródeł". W religioznawstwie tymi różnymi źródłami jest bogactwo tekstów religijnych na świecie - Biblii różnych wyznań, Talmudu, Koranu, Bhagavad-Gity i wielu innych ciekawych poznawczo oraz duchowo źródeł. Jednak wydaje się, że

Przytoczone w dalszej części artykułu cele i wymagania kształcenia dotyczące edukacji szkolnej w Polsce pochodzą z tego dokumentu. 
w sytuacji nieobecności religioznawstwa w szkole, zasób takich tekstów nie będzie omawiany przez ucznia.

Na tym etapie analizy Podstawy programowej nietrudno zauważyć, że owe wybrane cele i umiejętności, spodziewane do osiągnięcia w kształceniu szkoły podstawowej, są ograniczone przez brak możliwości zapoznania ucznia z różnymi religiami świata w osobnym przedmiocie. Jednak tematyka religioznawcza rozproszona treściowo jest obecna $w$ niektórych elementach programowych innych lekcji przedmiotowych o profilu humanistycznym. Przyjrzyjmy się obecnym rozwiązaniom, wynikającym z dokumentu, dotyczącym II etapu edukacyjnego (klasy IV-VIII).

\section{Cele kształcenia poszczególnych przedmiotów a edukacja religioznawcza}

W zakresie języka polskiego $\mathrm{w}$ celach kształcenia ogólnego przyjęto, iż zadaniem nauczyciela tego przedmiotu jest między innymi: „rozwijanie w uczniu ciekawości świata, motywacji do poznawania kultury własnego regionu oraz dziedzictwa narodowego" (pkt 3) oraz "kształtowanie postawy otwartości wobec innych kultur i szacunku dla ich dorobku" (pkt 4). Można oczywiście przyjąć, że lektury z zakresu polskiej i światowej literatury w pewnym stopniu umożliwią poznanie uczniom także wartości kulturowych obecnych w różnych religiach na świecie.

Również podstawa programowa dla języka obcego nowożytnego (w wersji II.2.DJ) przewiduje, iż może nastąpić: „wykorzystanie zajęć z języka obcego nowożytnego do rozwijania wrażliwości międzykulturowej oraz kształtowania postawy ciekawości, szacunku i otwartości wobec innych kultur, niekoniecznie tylko tych związanych z językiem docelowym, na przykład przez zachęcanie uczniów do refleksji nad zjawiskami typowymi dla kultur innych niż własna, stosowanie odniesień do kultury, tradycji i historii kraju pochodzenia uczniów oraz tworzenie sytuacji komunikacyjnych umożliwiających uczniom rozwijanie umiejętności interkulturowych" (pkt 9). Wydaje się, że nauka języka angielskiego, niemieckiego, czy rosyjskiego - jeśli nie będzie ograniczona do samego kształcenia językowego w obszarze gramatyki i słów, ale zostanie wykorzystana także do poznania wartości kulturowych, jakie znajdują się w Wielkiej Brytanii, Niemczech, czy Rosji - mogłaby zawierać też komponent religioznawczy (każdy z tych wpływowych krajów posiada swoje odrębne dziedzictwo religijne - anglikanizm, luteranizm czy prawosławie). Jednak wątpliwe jest, czy nauczyciel języka obcego nowożytnego będzie w stanie z uczniami zrobić taką lekcję 
(bądź szereg spotkań) w sposób niepowierzchowny, zważywszy, iż jego głównym zadaniem jest wpajanie umiejętności językowych.

Stosunkowo dużo nawiązań do religii można zauważyć w celach kształcenia na przedmiocie historia. Podstawa programowa przewiduje tutaj dla klas V-VIII między innymi następujące umiejętności nabyte przez ucznia: "charakteryzuje strukturę społeczeństwa i system wierzeń w Egipcie, Grecji i Rzymie, religię starożytnego Izraela; wyjaśnia różnicę między politeizmem a monoteizmem” (pkt 3), „umiejscawia w czasie i przestrzeni narodziny oraz rozprzestrzenianie się chrześcijaństwa" (pkt 6), dalej dla części II Bizancjum i świat islamu: „umiejscawia w czasie i przestrzeni zasięg ekspansji arabskiej i wyjaśnia wpływ cywilizacji muzułmańskiej na Europę" (pkt1). W części IX Złoty wiek w Polsce na tle europejskim planuje się, iż uczeń: „wymienia przyczyny i następstwa reformacji, opisuje cele i charakteryzuje działalność Marcina Lutra i Jana Kalwina oraz przedstawia okoliczności powstania Kościoła anglikańskiego” (pkt 2), a także „wyjaśnia cele zwołania soboru trydenckiego i charakteryzuje reformę Kościoła katolickiego" (pkt 3). Podobnie w dziale X Początki Rzeczypospolitej Obojga Narodów przewiduje się, że uczeń: „charakteryzuje stosunki wyznaniowe i narodowościowe w Rzeczypospolitej; wyjaśnia główne założenia konfederacji warszawskiej". W jednym z ostatnich działów (zapewne realizowanych w klasie VIII) ulokowano rolę Jana Pawła II i jego wpływ na przemiany społeczne oraz polityczne w Polsce.

Na lekcji historii Podstawa programowa przewiduje zatem sporo nawiązań o kontekście religioznawczym. Jednak rozległość treści tego przedmiotu powoduje, iż niestety i w tym przypadku wiadomości o religiach świata, jakie nabędzie uczeń, będą powierzchowne i podatne na zapomnienie. Dotyczyć to będzie szczególnie informacji odnośnie religii starożytnych oraz świata arabskiego, przerabianych w okolicach klasy $\mathrm{V}$, co powoduje, że bez ponownych nawiązań uczeń nie utrwali sobie tej wiedzy w klasach późniejszych.

Pewne relacje $\mathrm{z}$ informacjami religioznawczymi mogą pojawić się $\mathrm{w}$ ramach Podstawy programowej do przedmiotu Wiedza o Społeczeństwie. W części IV Prawa człowieka do tego przedmiotu, w punkcie 7 spodziewane jest, że uczeń: „przedstawia przykłady działań organizacji pozarządowych na rzecz ochrony praw człowieka; uzasadnia potrzebę przeciwstawiania się zjawiskom braku tolerancji wobec różnych mniejszości". Polska jest krajem o bardzo dużej przewadze katolików nad wyznawcami innych religii, niemniej w naszym kraju mamy mniejszościowe wspólnoty wyznaniowe, nie tylko na Podlasiu i Śląsku Cieszyńskim. Z kolei, w rozdziale VIII Wspólnoty narodowe/etniczne i ojczyzna, uczeń: „uzasadnia, że można pogodzić różne tożsamości społeczno-kulturowe (regionalną, narodową/etniczną, państwową/ obywatelską, europejską); rozpoznaje przejawy ksenofobii, w tym rasizmu, 
szowinizmu i antysemityzmu, oraz uzasadnia potrzebę przeciwstawiania się tym zjawiskom" (pkt 5). Wydaje się, że aby zrozumieć, czym jest antysemityzm, trudno uniknąć informacji religioznawczych, na przykład czym był kiedyś antyjudaizm, na czym polegały religijne stereotypy na temat Żydów (zarzuty o porywanie dzieci na złożenie ofiar, rzekome profanacje komunii itp.).

Dość sporo odniesień do religioznawstwa przewidzianych jest w Podstawie w zapisach dla przedmiotu Etyka. W punktach 7 i 9 zapisano, że uczeń: „wyjaśnia różnice między etyką a moralnością oraz moralnością a obyczajowością, prawem i religią” oraz „wie, że ludzie reprezentujący różne kultury mogą wyznawać różne wartości i przekonania moralne; wyjaśnia, czym jest wielokulturowość". W kształceniu na tym przedmiocie przewidziano również osobny dział VI, zatytułowany Człowiek wobec Boga (sacrum). Znalazło się tutaj siedem punktów odnoszących się do wiedzy ucznia: „wie, że są ludzie wierzący w istnienie Boga i ludzie niewierzący w istnienie Boga”; , wie, że dla ludzi wierzących Bóg jest najwyższym dobrem (wartością) i źródłem prawa moralnego"; „wyjaśnia, czym są wartości chrześcijańskie, objaśnia ich uniwersalne znaczenie (roszczenie do uniwersalności)"; , wie, czym jest moralność świecka (laicka)”; „uzasadnia, dlaczego należy okazywać szacunek zarówno ludziom wierzącym, jak i niewierzącym”; „charakteryzuje komponenty moralne wielkich religii: judaizmu, hinduizmu, buddyzmu, chrześcijaństwa, islamu”; , ,nie dyskryminuje innych ludzi, ze względu na ich przekonania dotyczące sfery Sacrum".

Ten cenny poznawczo blok z punktu widzenia religioznawstwa nie jest jednak w pełni zadowalający, ponieważ koncentruje się głównie na moralnym charakterze religii. Etyka stanowi oczywiście ważny aspekt różnych kościołów i wyznań, gdyż w zasadzie każde z nich ma konkretną doktrynę oraz swoją etykę religijną. Niemniej, religii nie można sprowadzić do samej moralności. Obok doktryny, poszczególne kościoły i związki wyznaniowe cechuje również posiadanie rytuałów oraz określonych instytucji. Tego na etyce już omówić nie można, gdyż przedmiot ten zakresowo skupia się na moralności i obyczajowości.

Ponadto, etyka ma odrębny status lekcyjny w polskich placówkach oświatowych. Zauważa to ustawodawca w Podstawie programowej, pisząc: „(...) ze względu na specyfikę zajęć z etyki jako zajęć nieobowiązkowych, od nauczyciela etyki wymagana jest daleko idąca autonomia, wyrażająca się $\mathrm{w}$ umiejętnym zaplanowaniu pracy dydaktycznej z powierzoną mu grupą uczniów oraz we właściwym doborze tematyki zajęć dostosowanej do wieku i możliwości intelektualnych, emocjonalnych i społecznych uczniów". Taka formuła zajęć nie sprzyja zbyt dokładnemu omawianiu treści na lekcjach, jak i możliwości dotarcia $\mathrm{z}$ wiedzą religioznawczą do większej grupy uczniów (etyka jest przedmiotem fakultatywnym). 


\section{Religia a religioznawstwo w polskiej szkole}

Po analizie Podstawy programowej dochodzimy do problemu, który nie jest wprost obecny w tym dokumencie, ale jego określona formuła została od 1991 roku wdrożona $\mathrm{w}$ polskich szkołach. Jest to zagadnienie lekcji religii. Przyjęte od początku lat dziewięćdziesiątych rozwiązanie, kontynuowane po dzień dzisiejszy, przewiduje obowiązkową obecność na lekcji religii ucznia (obecnie najczęściej w wymiarze $2 \mathrm{~h}$ w tygodniu), chyba że rodzic lub opiekun niepełnoletniego ucznia zadeklaruje chęć zapisania na etykę. Z różnych powodów rozwiązanie to ma wiele wad w edukacji szkolnej.

Przede wszystkim, stworzono wrażenie, że etyka stanowi przedmiot ideowo skierowany przeciw religii. Nie jest tak zarówno z powodów treściowych (istnieją zarówno etyki świeckie, jak też etyki religijne), jak i funkcjonalnych - teoretycznie ustawodawca przewidział, że uczeń może chcieć uczęszczać zarówno na religię, jak i na etykę. Dlaczego nie miałby być zainteresowany zarówno religią, jak i etyką?

Jednak w praktyce szkolnej ucznia albo się nie informuje o takiej możliwości, albo po prostu wychowanek szkoły zwyczajnie ze względów praktycznych wybiera jeden z tych przedmiotów, chcąc mieć mniej godzin lekcyjnych w szkole. Często jest to i tak religia, nawet jeśli uczeń wolałby chodzić na etykę. Dzieje się tak z różnych powodów, wśród których można wymienić: większy dostęp do kadry katechetów niż etyków na rynku oświatowym (tych pierwszych jest znacznie więcej), niekorzystny układ lekcji (gdzie dla etyki uczeń musiałby dłużej zostawać w placówce niż pozostali uczniowie), jak i czasami presja lokalnych władz kościelnych (szczególnie w mniejszych miejscowościach).

Należy zauważyć, iż religia w obecnej postaci jest de facto katechezą katolicką. Uczy się zatem $\mathrm{w}$ ramach tego przedmiotu wiadomości na temat katolicyzmu. Założenia są tutaj normatywne - uczeń ma nie tylko nabyć wiadomości na temat Kościoła katolickiego, ale czynnie rozwijać własną wiarę. Takie rozwiązanie jest odległe od podejścia religioznawczego, gdzie nie powinno się mieszać porządku wiedzy z porządkiem wiary. Religioznawca może oczywiście być wierzący, ale nie powinien tego wprost deklarować jako nauczyciel, gdyż inaczej wyrażałby określone sądy normatywne i nie nauczał już jako religioznawca. $W$ tej perspektywie ważna jest również umiejętność porównywania różnych religii na świecie. Nawet w ramach chrześcijaństwa mamy obecnie wielość denominacji na świecie. W świecie protestanckim widoczne są kolejne „fale” nowej religijności. Niezwykle popularny, szczególnie w Ameryce Południowej (z której wywodzi się obecny papież Franciszek), jest tak zwany ruch zielonoświątkowy (pentekostalizm), nawet w krajach tra- 
dycyjnie katolickich (jak Brazylia, Argentyna), intensywnie w ostatnich dekadach wypierający katolicyzm z przestrzeni publicznej ${ }^{15}$.

Nauczanie religii w Polsce podlega kontroli Kościoła katolickiego. Obecnie jeszcze obowiązuje podręcznik Podstawa programowa katechezy z 2010 roku, choć w fazie zaawansowanych przygotowań jest już nowa Podstawa, adekwatna do obecnych reform edukacyjnych, zatwierdzona w roku 2018 przez Episkopat (podręczniki na niej oparte mają jednak wejść w 2019 roku) ${ }^{16}$. Katechetyczne cele Autorów widać w poszczególnych wymaganiach szczegółowych wobec ucznia. Wymieńmy kilka przykładowych. Uczeń klasy IV-VI: „wskazuje, dlaczego chrześcijanin powinien poznawać Objawienie Boże i nauczanie Kościoła”; "opisuje działanie Ducha Świętego w Kościele i na świecie"; "przejawia postawę szacunku i zaufania Bogu”; „wskazuje w jaki sposób może dawać świadectwo wiary w podstawach życia codziennego"17. Są to wymagania aksjologiczno-wychowawcze w stosunku do postawy i zachowania ucznia. Oczywiście, za zgodą rodziców, szkoła ma prawo nie tylko nauczać, ale i wychowywać uczniów, przygotowywać ich do świata wartości, w tym wartości katolickich. Katecheza szkolna, przy wszystkich wyżej wymienionych zastrzeżeniach, jest też pewną postacią przedmiotu humanistycznego, gdyż dotyczy ważnego aspektu człowieczeństwa i kultury, jakim jest religia katolicka. Wydaje się jednak, że edukacja humanistyczna bez komponentu religioznawczego jest uboższa. Dlaczego katolik nie miałby również mieć wiedzy o innych religiach na świecie? Inną kwestią jest również to, że przecież niewierzący uczeń może również być zainteresowany katolicyzmem z perspektywy religioznawczej, chcąc na przykład zrozumieć historię religii i współczesne relacje między państwem a kościołem.

Można dostrzec w Podstawie programowej katechezy także elementy religioznawstwa w kilku miejscach. Dla III etapu edukacyjnego - gimnazjum - przewidziano, że uczeń na religii: „porównuje religie świata, określając specyfikę chrześcijaństwa", a w treściach zaplanowano naukę elementów religii niechrześcijańskich, to jest powstanie, podstawowe założenia i informacje o występowaniu judaizmu, buddyzmu, hinduizmu i islamu ${ }^{18}$. Problem w tym, że zaraz pod tym, w tej samej rubryce treściowej, umieszczono także "cechy charakterystyczne sekt i metody ich działania oraz skutki przynależności do sekt”, uczeń natomiast „uzasadnia właściwą postawę chrześcijanina wobec sekt” ${ }^{\prime 19}$. Inne religie są $\mathrm{w}$ domyśle kojarzone z sektami, z czymś przed

${ }^{15}$ L. Jańczuk, Przyczyny rozwoju pentekostalizmu w Ameryce Łacińskiej, Rocznik Teologiczny, 2016, 58(1), s. 123-135.

${ }^{16}$ Episkopat przyją nowa podstawe programowa katechezy, https://ekai.pl/episkopat-przyjalnowa-podstawe-programowa-katechezy/ [dostęp: 15.02.2019].

${ }_{17}$ Podstawa programowa katechezy Kościoła katolickiego w Polsce, Kraków 2010, s. 40-42.

18 Tamże, s. 58.

19 Tamże. 
czym potencjalnie katolik powinien się bronić. Takie defensywne nastawienie nie sprzyja dyskursowi religioznawczemu. Wśród badaczy pojawia się krytyka obecnej edukacji religijnej, gdzie zauważa się nieefektywność obecnych metod lekcji religii bądź chęć pojednawczego wygaszenia sporu etyka - religia w polskiej, także wśród duchownych zajmujących się pedagogiką, religii ${ }^{20}$.

\section{Próby i perspektywy uobecnienia religioznawstwa w edukacji szkolnej}

Pedagogika porównawcza dostarcza różnych modeli nauczania religii w Europie. Ciekawe jest rozwiązanie niemieckie, w ramach którego również istnieje przedmiot „religia” (katolicka bądź ewangelicka, zależnie od miasta czy landu). Podręczniki do nauki religii w Niemczech mają charakter dużo bardziej religioznawczy. Przedstawia się w nich różne religie, nie przesądzając, która z nich jest aksjologicznie ważniejsza. Uczeń ma możliwość porównania Biblii z Koranem i Talmudem, w tych podręcznikach wiele jest także miejsca na konieczność dialogu z wyznawcami innych religii. Jest to model edukacji religijnej opartej na dialogu, gdzie konfesyjność jest znacznie mniej akcentowana niż w polskiej edukacji religijnej ${ }^{21}$.

Pojawiały się próby opracowania w Polsce odrębnych podręczników do przedmiotu religioznawstwo ${ }^{22}$, jak i pilotażowe próby wprowadzenia takiego przedmiotu do szkół. Jednak bez trwałych efektów. Przyczyny były różnorodne. W edukacji szkolnej okresu PRL wprowadzanie religioznawstwa do szkół przez zwolenników katolickich wartości było odbierane jako element ofensywy ówczesnej, oficjalnej ideologii marksistowsko-leninowskiej. Wrażenie to nie było mylne, gdyż istotnie działania ówczesnych władz oświatowych, przygotowujących podręcznik do religioznawstwa na podstawie sowieckiego podręcznika Ugrinowicza ${ }^{23}$, były częściowo inspirowane z pobudek ideologicznych, jawnie zmierzających do wspierania ateizacji społeczeństwa i szkoły. Działaniom tym próbował przeciwdziałać pod koniec lat osiemdziesiątych XX wieku krakowski Instytut Religioznawstwa Uniwersytetu Jagiellońskiego, którego pracownicy w specjalnej ekspertyzie doradzali, aby wprowadzić przedmiot religioznawstwo do szkół, ale bez uwikłań

${ }^{20}$ D. Stępkowski, Szkoła miejscem ksztattowania kompetencji moralno-etycznej i kompetencji religijnej, Paedagogia Christiania, 2015, 1(35), s. 231.

${ }^{21}$ E. Zalewska, Dialog jako podstawowy wymiar relacji w sferze sacrum i profanum w niemieckich podręcznikach do edukacji religijnej, Przegląd Religioznawczy, 2018, 3(269), s. 17-38.

${ }_{22}$ Zob. H. Grzymała-Moszczyńska, J. Majchrowski (red.), Religioznawstwo. Podręcznik dla nauczyciela, Warszawa 1989.

${ }^{23}$ Zob. D.M. Ugrinowicz, Wstęp do religioznawstwa teoretycznego, Warszawa 1977. 
wspierających określony system aksjologiczny przeciw innemu ${ }^{24}$. Zaproponowano alternatywny program lekcji religioznawstwa, przewidziany dla szkół średnich. Proponowano wprowadzenie na 32 godzinach lekcyjnych 16 tematów, składających się na 4 bloki: (1) religia jako zjawisko społeczne, (2) religie współczesnego świata, (3) kościoły, religijność, problematyka wyznaniowa w PRL, (4) problemy światopoglądu.

Z perspektywy czasu widać, że i ten program uległ dezaktualizacji, jednak nadal przynajmniej pierwszy i drugi moduł jest czymś, co mogłoby wzbogacić polską edukację szkolną. Wciąż aktualna wydaje się również większość celów nauczania religioznawstwa, postulowanych już wcześniej, takich jak: (1) ukazywanie źródeł historii i funkcji religii, (2) pokazanie humanistycznego wymiaru religii, (3) rozwijanie refleksji, (4) kształtowanie tolerancji, (5) budzenie zainteresowania problematyką moralności i obyczajowości różnych grup religijnych ${ }^{25}$. Wszystkie te cele nauczania są wciąż aktualne jako cenne postulaty w polskiej edukacji szkolnej.

\section{Zakończenie}

Wiele wskazuje na to, że problem nieobecności religioznawstwa w polskiej edukacji będzie się nasilać - wraz z „pełzającą” sekularyzacją społeczeństwa polskiego, napływem migrantów (warto zauważyć, że znaczną większość dużej diaspory Ukraińców mieszkających w Polsce stanowią prawosławni bądź grekokatolicy), zmianami w postawach polskiej młodzieży, która coraz mniej akceptuje model autorytatywny nauczania ${ }^{26}$, jak i przemianach aksjologicznych w samym społeczeństwie ${ }^{27}$.

Trafną refleksją dzieli się w tej kwestii Szymon Dąbrowski:

współczesne pokolenie jest niejako naznaczone techniką, przez co uznaje ją za coś oczywistego i niezbywalnego. Katecheza szkolna, będąc z założenia w opozycji do techniki i szybkich mediów, staje również w opozycji do młodego człowieka. Ta opozycja ma swoje dalsze konsekwencje - nauczanie religijne, nie biorąc pod uwagę i dezawuując tendencje technologizacji świata, ponownie dzieli i antagonizuje całą strukturę dzisiejszej rzeczywistości społecznej. Młode pokolenie jest w nieustannym chaosie rozpadu

${ }^{24}$ H. Hoffman, A. Książek, Religioznawstwo w szkole - polskie doświadczenia, Pantheon. Religionistický Časopis, 2010, 6, s. 38.

${ }^{25}$ Stan religioznawstwa w szkołach średnich. Wstępny raport z badań, Instytut Religioznawstwa Uniwersytetu Jagiellońskiego, Kraków 1988, s. 13-15 za: H. Hoffman, A. Książek, Religioznawstwo w szkole, s. 42.

${ }^{26}$ J. Baniak, Od akceptacji do kontestacji: moralność katolicka w krytycznym ujęciu i ocenie młodzieży polskiej, Warszawa 2015.

${ }_{27}$ The Age Gap in Religion Around the World, https:/ / www.pewforum.org/2018/06/13/the-age-gap-in-religion-around-the-world/, [dostęp: 24.04.2019]. 
i włączania na nowo, jest coraz mniej rzeczy pewnych, płynność dominuje w każdym przejawie ludzkiego życia. Jednocześnie istnieje jednak powierzchowna, lecz fundamentalna pewność o istnieniu sfery wolności, która przynależy każdemu człowiekowi w sposób automatyczny i absolutny. Katechetyka katolicka posługuje się często podziałem na rzeczywistość godną i niegodną, moralną i niemoralną, gdzie sfera wirtualna, medialna czy internetowa nie lokuje się raczej w tej pierwszej. Działanie to separuje niejako dwa światy, sacrum i profanum, a co najgorsze automatycznie umiejscawia to młodego człowieka w tej drugiej przestrzeni ${ }^{28}$.

Dobrym przykładem, ilustrującym problem zrozumienia języka używanego przez młodzież w przestrzeni medialnej, są memy religijne. Kwestię tę przebadałem $\mathrm{w}$ innych publikacjach ${ }^{29}$, natomiast nowym zjawiskiem jest próba utrzymania kontroli przez instytucje kościelne nad twórczością religijną młodych katolików, którzy chcieliby w nowoczesny sposób przeżywać swoją wiarę. W przypadku memu wielkanocnego autorstwa Dayenu, przedstawiającego postać Chrystusa na tle cienia zajączka, ze strony krakowskiej kurii padł zarzut o profanację ${ }^{30}$. Kościół ma zatem problemy także ze zrozumieniem wrażliwości młodych osób, identyfikujących się z wartościami katolickimi, ale przeżywającymi je na swój sposób.

Znaczny spadek identyfikacji z wartościami religijnymi wśród młodych dorosłych w Polsce (przez których rozumie się tu osoby do 40. roku życia) zauważono w porównawczych badaniach Pew Research Center w 2018 roku (co ciekawe, równie duży spadek religijności zauważono wśród młodych dorosłych w islamsko-szyickim Iranie). Widać to także w stosunku społeczeństwa do poszczególnych przekonań religijnych w katolicyzmie. Na przykład, w badaniu CBOS z 2015 roku 30\% Polaków wierzy w reinkarnację (nieuznawaną w katolicyzmie), tylko 56\% wierzy w istnienie piekła. Wysoki odsetek nie wierzy w tak ważne prawdy dla katolicyzmu, jak zmartwychwstanie zmarłych $(29 \%)^{31}$.

Należy jednak pamiętać, iż spadek zainteresowania dogmatami i praktykami religijnymi, czy częściowa erozja tożsamości katolickiej, nie musi oznaczać braku zainteresowania zjawiskiem religii i duchowości (na co wskazuje rozwój postsekularyzmu w filozofii i kulturze ${ }^{32}$ ). Szkolnictwo polskie nie może rozwijać się w izolacji odnośnie przemian społeczno-kulturowych

${ }^{28}$ S. Dąbrowski, (Po)wolna edukacja religijna, [w:] Między ekskluzją a inkluzją w edukacji religijnej, red. M. Humeniuk, I. Paszenda, Wrocław 2017, s. 146.

${ }^{29}$ J. Iwanicki, Wybrane memy religijne. Semiologiczne studium przypadków, Humaniora. Czasopismo Internetowe, 2018, 1(21), s. 81-104.

${ }^{30}$ Oświadczenie Dayenu, https://www.facebook.com/search/top/?q=dayenu\&epa=SEARCH_BOX [dostęp: 24.04.2019].

31 CBOS, Komunikat z badań. Kanon wiary Polaków, 2015, 29, s. 8.

32 J. Iwanicki, Procesy sekularyzacyjne a filozofia sekularna i postsekularna. Tradycje i wspótczesność, Poznań 2014, s. 111-118. 
w swoim otoczeniu. Wiele wskazuje zatem, że dyskusja o kształcie nauczania religii w szkołach będzie się odnawiać. Być może wróci wówczas kwestia obecności religioznawstwa w edukacji szkolnej w Polsce.

\section{BIBLIOGRAFIA}

Baniak J., Od akceptacji do kontestacji: moralność katolicka w krytycznym ujęciu i ocenie młodzieży polskiej, Wydawnictwo Difin, Warszawa 2015.

CBOS, Komunikat z badań. Kanon wiary Polaków, 2015, 29.

Dąbrowski S., (Po)wolna edukacja religijna, [w:] Między ekskluzją a inkluzją w edukacji religijnej, red. M. Humeniuk, I. Paszenda, Instytut Pedagogiki Uniwersytetu Wrocławskiego, Wrocław 2017.

Drozdowicz Z. (red.), Zarys encyklopedyczny religii, Wydawnictwo Naukowe UAM, Poznań 1992.

Drozdowicz Z., Filozofia włoska w epoce Odrodzenia i Oświecenia, Wydawnictwo Naukowe WNS UAM, Poznań 2012.

Drozdowicz Z., Stachowski Z. (red.), Ilustrowana encyklopedia religii świata. Kościoły, wyznania, kulty, sekty, nowe ruchy religijne, Wydawnictwo Kurpisz, Poznań 2002.

Eliade M., Traktat o historii religii, przekł. J. Wierusz-Kowalski, Wydawnictwo Aletheia, Warszawa 2009.

Episkopat przyjąt nowa podstawe programowa katechezy, https://ekai.pl/episkopat-przyjalnowa-podstawe-programowa-katechezy/ [dostęp: 15.02.2019].

Grzymała-Moszczyńska H., Majchrowski J. (red.), Religioznawstwo. Podręcznik dla nauczyciela, Wydawnictwa Szkolne i Pedagogiczne, Warszawa 1989.

Hoffman H., Dzieje polskich badań religioznawczych 1873-1939, Wydawnictwo Uniwersytetu Jagiellońskiego, Kraków 2004.

Hoffman H., Książek A., Religioznawstwo w szkole - polskie doświadczenia, Pantheon. Religionistický Časopis, 2010, 6.

Iwanicki J., Procesy sekularyzacyjne a filozofia sekularna i postsekularna. Tradycje i wspótczesność, Wydawnictwo Naukowe WNS UAM, Poznan 2014.

Iwanicki J., Mediatyzacja treści religijnych we wspótczesnej kulturze popularnej i internetowej, Humaniora. Czasopismo Internetowe, 2017, 2(18).

Iwanicki J., Wybrane memy religijne. Semiologiczne studium przypadków, Humaniora. Czasopismo Internetowe, 2018, 1(21).

Jańczuk L., Przyczyny rozwoju pentekostalizmu w Ameryce Łacińskiej, Rocznik Teologiczny, 2016, 58(1).

Kot S., Historia wychowania, t. 1, Wydawnictwo Akademickie ŻAK, Warszawa 1994.

Mariański J., Sekularyzacja, desekularyzacja, nowa duchowość: studium socjologiczne, Zakład Wydawniczy Nomos, Kraków 2013.

Podstawa programowa katechezy Kościoła katolickiego w Polsce, WAM, Kraków 2010.

Oświadczenie Dayenu, https://www.facebook.com/search/top/?q=dayenu\&epa=SEARCH_BOX [dostęp: 24.04.2019].

Rozporządzenie Ministra Edukacji Narodowej z 14 lutego 2017 r. w sprawie podstawy programowej wychowania przedszkolnego oraz podstawy programowej kształcenia ogólnego dla szkoły podstawowej, w tym dla uczniów z niepełnosprawnością intelektualną w stopniu umiarkowanym lub znacznym, kształcenia ogólnego dla branżowej szkoły I stopnia, kształcenia ogólnego dla szkoły specjalnej przysposabiającej do pracy 
oraz kształcenia ogólnego dla szkoły policealnej, https:/ / www.infor.pl/akt-prawny/ DZU.2017.039.0000356,rozporzadzenie-ministra-edukacji-narodowej-w-sprawie-podstawy-programowej-wychowania-przedszkolnego-oraz-podstawy-programowej-ksztalcenia-ogolnego-dla-szkoly-podstawowej-w-tym-dla-uczniow-z-niepelnosp. html [dostęp: 15.02.2019].

Rozporządzenie Ministra Nauki i Szkolnictwa Wyższego z 20 września 2018 r. w sprawie dziedzin nauki i dyscyplin naukowych oraz dyscyplin artystycznych, https://www. infor.pl/akt-prawny/DZU.2018.186.0001818,rozporzadzenie-ministra-nauki-i-szkolnictwa-wyzszego-w-sprawie-dziedzin-nauki-i-dyscyplin-naukowych-oraz-dyscyplin-artystycznych.html [dostęp: 15.02.2019].

Stan religioznawstwa w szkołach średnich. Wstępny raport z badan, Instytut Religioznawstwa Uniwersytetu Jagiellońskiego, Kraków 1988.

Stępkowski D., Szkoła miejscem ksztattowania kompetencji moralno-etycznej i kompetencji religijnej, Paedagogia Christiania, 2015, 1(35).

The Age Gap in Religion Around the World, https:/ / www.pewforum.org/2018/06/13/the-age-gap-in-religion-around-the-world/, [dostęp: 24.04.2019].

Ugrinowicz D.M., Wstęp do religioznawstwa teoretycznego, Książka i Wiedza, Warszawa 1977.

Weber M., Etyka gospodarcza religii światowych, przekł. T. Zatorski, G. Sowiński, D. Motak, Zakład Wydawniczy Nomos, Kraków 2006.

Zalewska E., Dialog jako podstawowy wymiar relacji w sferze sacrum i profanum w niemieckich podręcznikach do edukacji religijnej, Przegląd Religioznawczy, 2018, 3(269).

Zależności między nowa klasyfikacja dziedzin i dyscyplin a wcześniej obowiązującym wykazym i systematyka OECD, https://konstytucjadlanauki.gov.pl/content/uploads/2018/09/ nowy-podzia-dyscyplin-tabela.pdf [dostęp: 24.04.2019].

Zduniak A., Religijność, duchowość, nowa duchowość - próba teoretycznego rozgraniczenia kluczowych pojęć wspótczesnej socjologii religii, Przegląd Religioznawczy, 2017, 2(264). 